Jurnal Kesehatan

Volume 12, Nomor 2, Tahun 2021

ISSN 2086-7751 (Print), ISSN 2548-5695 (Online) http://ejurnal.poltekkes-tjk.ac.id/index.php/JK

\title{
Literature Review: Efektivitas Interprofessional Education (IPE) terhadap Peningkatan Kemampuan dan Kompetensi antar Profesi Kesehatan
}

\section{Literature Review: The Effectiveness of Interprofessional Education (IPE) on the Improvement of Abilities and Competencies among Health Professionals}

\author{
Amaze Grace Davidz Morato ${ }^{1}$, Ni Luh Putu Eka Diarthini ${ }^{2}$, Desak Ketut Indrasari Utami ${ }^{3}$ \\ Fakultas Kedokteran, Universitas Udayana, Indonesia
}

\section{ARTICLE INFO}

\section{Article history}

Received date

31 May 2021

Revised date

02 Jun 2021

17 Jun 2021

Accepted date

03 Aug 2021

\section{Keywords:}

Abilities;

Competence;

Health Profession;

Interprofessional

Education (IPE).

\section{Kata kunci:}

Kemampuan;

Komtepensi;

Interprofessional

Education (IPE).

\author{
ABSTRACT/ ABSTRAK
}

Interprofessional Education (IPE) is a learning process between students from various health workers from different educational backgrounds, that interacting and collaborating to produce and provide promotive, preventive, curative, and rehabilitative health services. The implementation of the IPE program in academic education is important to help develop the concept of collaboration between health professionals to prepare and create better, professional, and competent health workers to deal with health problems. The purpose of this study was to determine how the effectiveness of interprofessional education in increasing the ability and competence of health professionals. The method in this study is a literature study article or narrative review in the form of a study of several research journals related to the effectiveness of interprofessional education on increasing abilities and competition between health professions obtained through Google Scholar, PubMed, and Science Direct. The benefits of IPE activities are students can learn to collaborate and function in a team and bring this knowledge, skills, and attitudes into future practice through enhancing several aspects such as communicating, collaborating, determining the roles and responsibilities of each profession, conflict management, decision making, sharing knowledge and skills and finally mutual respect between friends. Based on the cited literature review, it can be cited that interprofessional education (IPE) is a way to increase competence and collaboration skills between professions so that it can create health professionals who are professional, capable, and able to improve the quality of health services.
Interprofessional Education (IPE) merupakan proses pembelajaran antar mahasiswa dari berbagai tenaga kesehatan yang berasal dari latar belakang pendidikan yang berbeda, saling berinteraksi dan berkolaborasi untuk menghasilkan dan menyediahkan pelayanan kesehatan yang promotif, preventif, kuratif, dan rehabilitatif. Penerapan program IPE dalam pendidikan akademik merupakan hal yang penting untuk membantu pengembangan konsep kerjasama dan kolaborasi antarprofesional kesehatan, sehingga dapat mempersiapkan dan menciptakan tenaga kesehatan yang lebih baik, profesional, dan berkompeten untuk menghadapi masalah kesehatan. Tujuan dari studi ini adalah mengetahui bagaimana efektivitas penerapan interprofessional education terhadap peningkatan kemampuan dan kompetensi antar profesi kesehatan. Metode pada studi ini adalah studi literatur artikel atau narrative review berupa kajian dari beberapa jurnal penelitian yang berhubungan dengan efektivitas interprofessional education terhadap peningkatan kemampuan dan kompetensi antar profesi kesehatan yang didapatkan melalui Google Scholar, PubMed, dan Science Direct. Manfaat dari kegiatan IPE adalah mahasiswa dapat belajar berkolaborasi dan berfungsi didalam suatu tim dan membawa pengetahuan, keterampilan dan sikap ini ke dalam praktek di masa depan melalui peningkatan beberapa aspek seperti berkomunikasi, berkolaborasi, menentukan peran dan tanggung jawab dari masing-masing profesi, memanajemen konflik, pengambilan keputusan, berbagi pengetahuan dan keterampilan dan yang terakhir rasa saling menghormati antar teman. Berdasarkan kajian pustaka yang disitasi dapat disimpulkan bahwa interprofessional education (IPE) merupakan cara untuk meningkatkan kemampuan dan kompetensi kolaborasi antar profesi sehingga dapat menciptakan tenaga kesehatan yang professional, mampu bekerjasama, dan mampu menigkatkan kualitas pelayanan kesehatan.

Corresponding Author:

Amaze Grace Davidz Morato

Program Studi Sarjana Fisioterapi dan Profesi Fisioterapi, Fakultas Kedokteran, Universitas Udayana, Indonesia Email: amazegdm20@gmail.com 


\section{PENDAHULUAN}

Berbagai tantangan terhadap masalah kesehatan terjadi dalam era global ini. Kesehatan merupakan salah satu faktor penting untuk kehidupan manusia. World Health Organization (WHO) mendefinisikan kesehatan sebagai suatu keadaan atau kondisi baik itu fisik, mental, dan sosial yang sempurna dan ideal, dimana seseorang dapat hidup dalam kesejahteraan baik dari segi biologis, psikologis, dan sosial (World Health Organization, 2013). Salah satu faktor untuk mewujudkan kesejahteraan tersebut yaitu dimana seseorang harus memiliki kesehatan yang baik. Kesehatan yang baik merupakan salah satu aspek penting bagi kemajuan suatu negara. Masyarakat dapat mencapai kondisi yang sehat apabila didukung dengan pelayanan kesehatan yang berkualitas, bermutu, dan prima, sehingga diperlukan adanya kolaborasi antar tenaga kesehatan yang baik dan professional supaya dapat meningkatkan kualitas dan kompetensi pelayanan kesehatan (Asmara, et al., 2019; Kusumaningrum \& Anggorowati, 2018). Dalam praktek antar tenaga kesehatan, setiap individu memerlukan adanya tingkat keahlian, kemampuan, dan keterampilan dalam memberikan pelayana kesehatan, sehingga dengan adanya kemampuan tersebut setiap tenaga kesehatan dapat saling berbagi pengetahuan antar tenaga kesehatan yang lain melalui praktek kolaborasi supaya diharapkan dapat mempertahankan kualitas pelayanan kesehatan yang berfokus pada pemberian pelayanan kesehatan yang prima, berkualitas, dan bermutu di era globalisasi saat ini (Kusumaningrum \& Anggorowati, 2018).

World Health Organization (1988) menciptakan sebuah grand design tentang suatu pembentukan karakter kolaborasi dalam bentuk pendidikan formal yaitu berupa interprofessional education (Kusumaningrum \& Anggorowati, 2018; Wijoyo, et al., 2017; Wulandari, et al., 2018). Interprofessional Education (IPE) merupakan proses pembelajaran antar mahasiswa dari berbagai tenaga kesehatan yang berasal dari latar belakang pendidikan yang berbeda, saling berinteraksi dan berkolaborasi untuk menghasilkan dan menyediahkan pelayanan kesehatan yang promotif, preventif, kuratif, dan rehabilitatif (Asmara, et al., 2019; Kusumaningrum \& Anggorowati, 2018; Toman, Probandari, \& R, 2016).

Dalam konteks pelayanan kesehatan dapat terjalan dengan baik melalui sekelompok tim multiprofesional yang bersatu untuk menangani berbagai macam prosedur pelayanan pasien.
Dalam sekelompok tim kesehatan terdiri dari berbagai macam profesi yang bertanggung jawab atas tugas dan kewajiban yang berbeda-beda. Dibutuhkan adanya etika kerja yang kolaboratif supaya dapat menciptakan suasana kerja yang damai untuk mencapai satu tujuan yang sama (Titania, 2018). Penerapan program IPE dalam lingkup pendidikan akademik pelayanan kesehatan merupakan hal yang penting untuk membantu pengembangan konsep kerjasama dan kolaborasi antarprofesional kesehatan, sehingga dapat mempersiapkan dan menciptakan tenaga kesehatan yang lebih baik, profesional, dan berkompeten untuk menghadapi masalah kesehatan. (Kusumaningrum \& Anggorowati, 2018) Oleh sebab itu, program ini perlu untuk diperkenalkan kepada mahasiswa sedini mungkin sehinga dapat memfasilitasi mahasiswa dalam bekerja dan berkolaborasi dengan mahasiswa lain dari disiplin ilmu yang berbeda.

Fakultas Kedokteran (FK) di Universitas Udayana adalah salah satu institusi yang menerapkan program IPE ke dalam komunitas. Kegiatan IPE yang dilakukan di FK Universitas Udayana terdiri dari 7 program studi atau profesi yang berkolaborasi yaitu Pendidikan Dokter, Pendidikan Dokter Gigi, Ilmu Keperawatan, Fisioterapi, Psikologi, Ilmu Kesehatan Masyarakat, dan Farmasi. Tujuan dari kegiatan IPE ini adalah untuk mengajarkan dan melatih kemampuan berkolaborasi dan bekerjasama (teamwork) antar mahasiswa program studi kesehatan supaya bisa saling melengkapi dalam mengatasi permasalahan kesehatan bersama-sama di dunia kerja, sehingga ketika mahasiswa berada di lapangan diharapkan mahasiswa dapat mengutamakan kesembuhan dan keselamatan pasien, serta meningkatkan pemberian kualitas pelayanan kesehatan bersama dengan profesi kesehatan lainnya, oleh karena itu dalam literature review ini penulis ingin mengetahui efektivitas dari penerapan Interprofessional Education terhadap peningkatan kemampuan dan kompetensi antar profesi kesehatan.

Metode penelitian pada studi ini adalah studi literatur artikel atau narrative review berupa kajian dari beberapa jurnal penelitian yang berhubungan dengan efektivitas penerapan interprofessional education terhadap peningkatan kemampuan dan kompetensi antar profesi kesehatan yang didapatkan melalui Google Scholar, PubMed, dan Science Direct.

Berdasarkan literatur review maka didapatkan hasil penelitian yang menunjukkan berbagai variabel penelitian yang berhubungan dengan efektivitas interprofessional education, sesuai yang ditunjukkan pada Tabel 1 . 
Tabel 1. Berbagai Penelitian Efektivitas Penerapan Interprofessional Educaton terhadap Peningkatan Kemampuan dan Kompetensi antar Profesi Kesehatan

\begin{tabular}{ll}
\hline \multicolumn{1}{c}{ Penulis } & \multicolumn{2}{c}{ Judul } \\
\hline Toman, & Interprofessional \\
K.P., & Education $\quad$ (IPE): \\
Probandari, & Luaran Masyarakat \\
A.N., Timor & terhadap Pelayanan \\
R, A.B., & Kesehatan dalam \\
2016 & Praktik Kolaborasi di \\
& Fakultas Kedokteran \\
& Universitas Sebelas \\
& Maret
\end{tabular}

- Sampel: Pasien dan keluarga pasien ( $\mathrm{n}=7,4$ pasien dan 3 keluarga pasien)

- Tujuan penelitian: menanamkan kompetensi IPE sejak dini dengan retensi bertahap pada mahasiswa, sehingga mahasiswa dapat mengutamakan keselamatan pasien dan meningkatkan kualitas pelayanan kesehatan bersama dengan profesi kesehatan lain.

- Jenis penelitian: kualitatif

- Teknik sampling: purposive sampling dengan typical sample

- Intrumen penelitian: Attitudes Toward Health Care Teams (ATHCT) Scale

- Teknik analisis data: thematic content analysis

Romijn, A., $\quad$ Interprofessional - Subjek: Pelayan kesehatan

Teunissen, collaboration among P.W., De care professionals in Bruijne, obstetrical care: are M.C.,

Wagner, C.,

De Groot,

C.J.M., 2016 perceptions aligned?

( $\mathrm{n}=379,74$ dokter kandungan, 42 bidang klinis, 154 perawat dan 109 bidang perawatan primer)

- Tujuan penelitian: mengetahui apakah adanya perbedaan persepsi dalam kolaborasi interprofesional di dalam tim multidisiplin yang terdiri dari dokter kandungan, bidan dan perawat

- Desain penelitian: cross- sectional

- Jenis penelitian: kuantitatif

- Intrumen penilaian: Skala Pengukuran Kolaborasi Interprofessional (IPCMS)

\begin{tabular}{ll}
\hline Wulandari, & Penerapan \\
H., Dewi, & Interprofessional \\
S.R., & Education (IPE) \\
Purwara, & Untuk Meningkatkan \\
B.H., 2018 & Ketrampilan \\
& Kerjasama Tim
\end{tabular}

- Jenis penelitian: literature
review

\begin{tabular}{ll}
\hline Sulistyowati, & Interprofessional \\
E. 2019 & Education (IPE) \\
& Dalam Kurikulum \\
& Pendidikan Kesehatan \\
& Sebagai Strategi \\
& Peningkatan Kualitas \\
& Pelayanan Maternitas
\end{tabular}

\begin{tabular}{lll}
\hline Lapkin, S., & $\begin{array}{l}\text { A systematic review of } \\
\text { Levett- }\end{array}$ & - Jenis penelitian: Kuantitatif \\
thenes, T., & $\begin{array}{l}\text { interprofessional } \\
\text { education in health }\end{array}$ & \\
Gilligan, C., & Desain penelitian: meta-analisis \\
professional programs & \\
\hline Hutchison, & Great minds don't & - Jenis penelitian : Kuantitatif \\
M.S., Ennis, & think alike: & - Desain penelitian: cross-sectional \\
L., Shaw- & collaborative & - Tujuan penelitian: untuk \\
Battista, J., & maternity care at San & mengetahui bagaimana efektivitas \\
Delgado, A., & Francisco General & dalam kolaborasi antara dokter \\
Myers, K., & Hospital & kandungan dan CNMs terhadap \\
Cragin, L., & & perbedaan filosofis dalam \\
Jackson, & & penyediaan layanan kesehatan.
\end{tabular}

Persepsi masyarakat mengenai luaran dari
pelayanan kesehatan dengan interprofessional education adalah baik melalui pelayanan yang berpusat pada pasien dan komunikasi yang baik antara tim pelayanan kesehatan dengan pasien dan keluarga pasien, dan juga antar anggota dalam tim pelayanan kesehatan. Pelayanan kesehatan dengan pembelajaran IPE memperbaiki kondisi kesehatan dan meningkatkan wawasan kesehatan pasien dan keluarga pasien lebih baik (Toman, et al., 2016).

\section{Adanya perbedaan-perbedaan yang relevan terutama dalam soal persepsi bersama tentang kolaborasi antar perawat dan bidang, sehingga dibutuhkan adanya kolaborasi yang efektif antar profesi kesehatan untuk pemberian perawatan yang lebih terintegrasi (Romijn, et al., 2018).}

Mutu pelayanan kesehatan dapat meningkat dengan adanya kerjasama tim dari tenaga kesehatan. Mahasiswa tenaga kesehatan yang sebagai penyedia layanan kesehatan di masa depan perlu menerima pendidikan yang dapat memberi mereka kompetensi yang diperlukan untuk menjadi anggota tim yang efektif (Wulandari, et al., 2018).

Terbukti efektivitas dari IPE dalam
menciptakan tenaga kesehatan yang profesional, mampu bekerjasama, berkolaborasi, menghargai dan memahami profesi kesehatan yang lain. Penerapan IPE dalam pendidikan kesehatan di Indonesia sangat direkomendasikan dalam rangka mewujudkan palayanan kesehatan, termasuk pelayanan kesehatan maternitas yang lebih berkualitas (Sulistyowati, 2019).

\section{Sikap dan persepsi siswa terhadap kolaborasi} antar profesional dan pengambilan keputusan klinis dapat secara potensial ditingkatkan melalui pendidikan interprofesional (Lapkin, et al., 2013).

Kerjasama dan kolaborasi yang baik antara bidan dan dokter spesialis kandungan tercipta dengan mempertahankan nilai-nilai profesionalisme, kemandirian, dan saling ketergantungan (Hutchison, et al., 2011). 


\section{PEMBAHASAN}

\section{Interprofessional}

\section{Education}

(IPE)

merupakan salah satu konsep pendidikan terintegrasi melalui proses pelatihan dan kolaborasi pembelajaran antara multi-profesi atau berbagai mahasiswa tenaga kesehatan yang berinteraksi dan berkolaborasi antara satu dengan yang lain dalam jangka waktu tertentu untuk menghasilkan, menciptakan, dan menyediakan pelayanan kesehatan yang promotif, preventif, kuratif dan rehabilitatif untuk meningkatkan kompetensi profesional kesehatan (Fuadah, et al., 2014; Kusumaningrum \& Anggorowati, 2018; Pratiwi, Adespin, \& Soeharto, 2018). Kegiatan IPE ini dilakukan untuk mempersiapkan mahasiswa kesehatan dalam memberikan pelayanan kesehatan di dalam ruang lingkup lingkungan kolaborasi, sehingga di masa yang akan datang mahasiswa yang akan menjadi tenaga kesehatan dapat meningkatkan kualitas pelayanan, mempercepat kesembuhan, dan mengurangi kesalahan (Asmara, et al., 2019; Sulistyowati, 2019). Dalam program IPE ini, mahasiswa tenaga kesehatan diajarkan bagaimana dari berbagai profesi dapat saling belajar bersama untuk mengembangkan pengetahuan, keterampilan, dan sikap yang diperlukan supaya dapat memecahkan masalah kesehatan, serta bagaimana mahasiswa dapat belajar untuk memprioritaskan individu dan masyarakat dalam perilaku dan kompetensi interprofesional (Asmara, et al., 2019; Fuadah, et al., 2012; Titania, 2018; Wulandari, et al., 2018).

Menurut Muktamiroh, et al. (2019), implementasi IPE dengan mendata nilai profesionalisme perlu ditambahkan dalam pendidikan akademik supaya mahasiswa memiliki kemampuan kerjasama dan kolaborasi interprofesi, memodifikasi kegiatan yang telah dilakukan diinstitusi pendidikan serta memanfatkan beberapa infrakstruktur yang telah dimiliki dan modal lain yang telah dimiliki sebagai peluang (Muktamiroh, et al., 2019). Hal ini didukung oleh penelitian dari Pratiwi, et al. (2018) yang menunjukan bahwa terdapat hubungan yang positif dan signifikan antara kemampuan tim dengan kinerja mahasiswa pada pelaksanaan IPE, dimana mahasiswa memiliki persepsi, keterampilan, sikap, dan kemampuan yang baik dengan adanya penerapan program IPE dalam pendidikan akademik (Pratiwi, et al., 2018). Penelitian yang dilakukan oleh Liaw, et al. (2014) juga menunjukan bahwa pelatihan interprofesional dalam program sarjana memberikan perkembangan kinerja kerja dalam tim interprofesional dan kemampuan berkomunikasi yang bermanfaat bagi keselamatan pasien (Liaw, et al., 2014).

Interprofessional Education merupakan pembelajaran yang dilakukan secara langsung oleh mahasiswa disiplin ilmu sesuai dengan permasalahan di lapangan, sehinga mahasiswa dapat menganalisis dan mengambil keputusan secara mandiri dengan pertimbangan yang tepat melalui sikap kerja yang baik, terampil dan dilaksanakan dalam usaha yang konsisten (Pratiwi, et al., 2018). Penerapan program IPE menjadi salah satu dasar dalam pembentukan kolaborasi. Dimana kegiatan IPE ini diterapkan sebagai media kolaborasi antar profesional kesehatan dengan menanamkan pengetahuan dan keterampilan dasar sedini mungkin antar profesional melalui proses pendidikan, selain itu IPE dapat membantu pengembangan konsep kerja sama antar profesional dengan mempromosikan sikap dan tingkah laku yang positif antar profesi yang terlibat. Pengembangan program IPE dimulai dengan tujuan utama yaitu untuk meningkatkan pelayanan kesehatan yang berpusat pada kesembuhan dan keselamatan pasien. Pendekatan interprofesional akan memfasilitasi mahasiswa dari satu disiplin ilmu untuk belajar dari disiplin ilmu lainnya, sehingga dapat meningkatkan keterampilan baru mahasiswa, memperkaya keterampilan khusus yang dimiliki oleh masing-masing disiplin, dan mampu bekerja sama lebih baik dalam lingkungan tim yang terintegrasi (Kusumaningrum \& Anggorowati, 2018; Pratiwi et al., 2018). Menurut Anwar \& Rosa (2019), IPE memiliki potensi yang positif dalam mempengaruhi sikap dan persepsi terhadap kolaborasi antarprofesional dan meningkatkan efektivitas pengambilan keputusan klinis dan kualitas perawatan yang lebih baik dan terjamin (Anwar \& Rosa, 2019).

Dalam dunia kesehatan, praktik kolaborasi adalah hal yang sangat penting. Permasalahan pasien yang dinamis dan kompleks tidak hanya dapat ditagani oleh satu profesi kesehatan, melainkan harus melibatkan berbagai profesi kesehatan (Pratiwi, et al., 2018). Kerja sama tim dalam kolaborasi IPE adalah proses yang dinamis dan kompleks yang melibatkan dua atau lebih profesi kesehatan yang memiliki pengetahuan dan keahlian yang berbeda, membuat penilaian dan perencanaan bersama, serta mengevaluasi bersama perawatan yang akan diberikan kepada pasien melalui kolaborasi yang independen, komunikasi yang terbuka, dan pengambilan keputusan bersama untuk meningkatkan kualitas pelayanan kesehatan. Hambatan dalam kolaborasi antar petugas kesehatan yang tidak baik menjadi 
penyebab utama terjadinya medical error, fragmanted care, pelayanan yang tumpang tindih, konflik interprofesional, keterlambatan pemeriksaan dan tindakan, kejadian yang tidak diharapkan yang dapat menimbulkan kerugian dan bahaya, bahkan dapat mengancam jiwa pasien (Pratiwi, et al., 2018; Titania, 2018). Menurut penelitian dari Toman, et al. (2016), membuktikan bahwa lemahnya hubungan antara tim kesehatan dengan pasien dan keluarga pasien, dan rendahnya bantuan serta dukungan tenaga kesehatan terhadap kesehatan pasien mengakibatkan menurunya kualitas pelayanan kesehatan yang diberikan dalam melakukan tidak lanjut terhadap kesehatan pasien. Perawatan pasien dengan penerapan IPE membuat partisipasi pasien lebih baik dalam membuat keputusan untuk perawatan, memberikan dampak positif pada kepuasan pasien, mengurangi medical errors, dan meningkatkan manajemen pelayanan kesehatan dalam perawatan pasien (Toman, et al., 2016).

Bekerja dalam sebuah tim akan melibatkan sekelompok orang dengan keahlian dan perspektif yang berbeda yang harus siap untuk melepaskan profesional otonomi mereka supaya dapat bekerja dengan orang lain untuk mendapatkan hasil yang lebih baik untuk tim. Karakteristik kerja sama tim yang kolaboratif adalah sekelompok profesional yang mempunyai tanggungjawab bersama, berbagi pemecahan masalah bersama, berbagi keputusan bersama, dan melatih komunikasi interprofesi yang berkontribusi penting untuk kerja sama tim yang efektif. Beberapa faktor yang dapat mempengaruhi keterampilan seseorang dalam kerjasama tim yaitu kecerdasan emosional dan intelegensia, kepribadian seseorang, kemampuan komunikasi, hubungan interpersonal, dan kemampuan beradaptasi. Dalam suatu tim agar mempunyai hubungan kerja yang nyaman dan efektif dalam praktik kolaborasi dibutuhkan adanya hubungan yang kooperatif antara angota yang satu dengan yang lain. Karakteristik hubungan yang kooperatif adalah hubungan yang didasari dengan adanya kepercayaan, rasa saling menghargai, komunikasi yang terbuka, dan ingin mendengarkan pendapat dari anggota tim yang lain (Wulandari, et al., 2018).

Manfaat dari kegiatan IPE adalah mahasiswa dapat belajar berkolaborasi dan berfungsi didalam suatu tim dan membawa pengetahuan, keterampilan, dan sikap yang dipelajari ke dalam praktek di masa depan bersama profesi kesehatan yang lain untuk kesembuhan dan keselamatan pasien. Praktek kolaborasi bukan hanya diperlukan dalam kesembuhan dan keselamatan pasien, tetapi juga untuk meningkatkan kepuasan serta terciptanya mutu pelayanan kesehatan yang prima dan baik (Pratiwi, et al., 2018). Dalam kegiatan ini, mahasiswa juga diajarkan bagaimana bekerjasama dalam berbagai aspek seperti berkomunikasi, berkolaborasi, menentukan peran dan tanggung jawab dari masing-masing profesi, memanajemen konflik, pengambilan keputusan, berbagi pengetahuan dan keterampilan, dan yang terakhir bagaimana menumbuhkan rasa saling menghormati antar teman (Asmara, et al., 2019; Fuadah, et al., 2012; Kusumaningrum \& Anggorowati, 2018; Romijn, et al., 2018; Wulandari, et al., 2018).

Hal pertama yang dipelajari dari program kegiatan IPE yaitu komunikasi, dimana kemampuan tenaga kesehatan untuk berkomunikasi secara efektif termasuk mangamati, mendengarkan, menjelaskan, dan berempati, secara signifikan memengaruhi hasil layananan kesehatan dan persepsi kepuasan pasien (Anwar \& Rosa, 2019). Dari kegiatan ini mahasiswa dapat mempelajari bagaimana tata cara berkomunikasi yang baik, bagaimana menyampaikan pesan yang baik dan sopan pada teman dan masyarakat, rasa toleransi untuk memahami prioritas dari kegiatan pada masing-masing program studi, memahami kemampuan untuk meningkatkan fungsi tim dalam menangani hambatan secara optimal, meningkatnya kepercayaan dalam komunikasi dengan orang lain dan meningkatkan keterampilan komunikasi baik dalam kelompok interprofesional maupun masyarakat (Asmara, et al., 2019; Fuadah, et al., 2012; Liaw, et al., 2014; Romijn, et al., 2018; Sulistyowati, 2019; Wulandari, et al., 2018).

Hal kedua yang dipelajari dari IPE yaitu kolaborasi, kolaborasi dalam tim kesehatan sangatlah penting karena masing-masing profesi tenaga kesehatan memiliki pengetahuan, keterampilan, kemampuan, keahlian, dan pengalaman yang berbeda (Titania, 2018). Dalam kegiatan IPE ini mengajarkan bagaimana mahasiswa dapat membuka dan mencari wawasan secara lebih luas dan komprehensif, belajar menyamakan persepsi untuk menyelesaikan masalah bukan hanya dari satu profesi, memberikan dukungan satu sama lain tanpa adanya perbedaan antar profesi, berkolaborasi dengan orang lain melalui problem solving dan pengambilan keputusan bersama secara tim untuk mengoptimalkan kekuatan dalam memberikan perawatan untuk mewujudkan health care (Fuadah, et al., 2012; Romijn, et al., 2018; Wulandari, et al., 2018). Efek positif lain dari penerapan kolaborasi yaitu memudahkan tenaga kesehatan untuk memiliki pengetahuan dan keterampilan yang lebih luas, 
sehingga tenaga kesehatan dapat menyelesaikan berbagai macam permasalahan lebih baik dan menciptakan suasana kerja yang lebih efektif dengan mengoptimalkan sumber daya manusia yang ada (Sudarmi, et al., 2020).

Hal ketiga yang dipelajari dari IPE yaitu peran dan tanggung jawab dari masing-masing program studi atau profesi kesehatan, dimana dari program IPE mengajarkan bahwa masing-masing profesi tidak ada yang memiliki proporsi lebih tinggi maupun lebih rendah, setiap anggota saling memahami peran dan tanggung jawab masingmasing profesi memiliki tujuan yang sama, mengakui keahlian masing-masing profesi, perbedaan dari setiap profesi dapat saling mengisi antara yang satu dengan profesi yang lain, dapat bertukar pikiran untuk menyelesaikan berbagai masalah yang dihadapi secara efektif dan efisien, serta meningkatkan keterampilan, memodifikasi peran untuk meningkatkan kinerja dan menghasilkan efek yang positif antarprofesional (Romijn, et al., 2018; Titania, 2018; Toman, et al., 2016).

Hal keempat yang dipelajari dari IPE yaitu manajemen konflik, dimana dari program ini mengajarkan bagaimana mahasiswa tenaga kesehatan dapat mengatur, mengelola, menenangkan diri, menahan ego, menyusun perencanaan dan pembagian tugas dengan baik, berusaha menemukan dan mencari solusi baik secara individu mampun kelompok yang bertujuan untuk membangun tim interprofesional dan menyelesaikan konflik secara efisien dan efektif (Romijn, et al., 2018; Titania, 2018; Wulandari, et al., 2018).

Hal kelima yang dipelajari dari IPE yaitu pengambilan keputusan, dimana dari program IPE mengajarkan bagaimana mahasiswa kesehatan dapat mengidentifkasi, koordinasi tentang perawatan dan atau mengatasi pendidikan kesehatan pasien dengan profesi kesehatan lainnya, menerapkan strategi atau pengambilan keputusan yang diputuskan secara musyawarah dan harus disepakati bersama oleh seluruh tenaga kesehatan sehingga kesejangan dan kesalahan dapat dihindari (Fuadah, et al., 2012; Romijn, et al., 2018; Wulandari, et al., 2018).

Hal keenam yang dipelajari dari IPE yaitu berbagi pengetahuan dan ketrampilan, dimana dari program IPE mengajarkan bagaimana mahasiswa harus saling bertukar informasi dengan terbuka, membuka diri dan pikiran untuk saling berbagi pengetahuan dan menerima masukan yang sesuai dengan kompetensi dari tenaga kesehatan yang lain (Fuadah, et al., 2012; Kusumaningrum \& Anggorowati, 2018).
Hal ketujuh atau hal terakhir yang dipelajari dari IPE yaitu rasa saling percaya dan menghormati, rasa saling memahami dan menerima keilmuan dari masing-masing profesi antar teman, dimana dari program IPE ini mahasiswa dapat belajar untuk percaya, menghormati, memahami, dan menerima keilmuan dari satu profesi antar profesi tenaga kesehatan lainnya, memiliki citra diri yang positif, mengakui profesi lain sebagai mitra kerja bukan bawahan tanpa memandang ras, agama, dan profesi (Titania, 2018). Sehingga dari beberapa hal tersebut, diharapkan dapat mengajarkan dan menciptakan mahasiswa menjadi tenaga kesehatan yang dapat mencapai tujuan akhir kolaborasi yaitu dengan menetapkan tujuan bersama dan menggunakan keahlian dari masingmasing profesi untuk bekerja dan memberikan perawatan secara kolaboratif dan profesional antar tenaga kesehatan untuk mencapai tujuan utama yang berpusat pada kesembuhan dan keselamatan pasien yang optimal (Fuadah, et al., 2012; Hutchison, et al., 2011; Kusumaningrum \& Anggorowati, 2018; Sulistyowati, 2019).

Pelaksanaan program IPE dapat bermanfaat dan memberikan keuntungan dari koordinasi yang lebih baik melalui kolaborasi interprofesi, sehingga dengan adanya penerapan IPE dalam pendidikan akademik membantu membangun kesiapan mahasiswa profesional kesehatan untuk meningkatkan komunikasi, memperkuat kerja tim, mengklarifikasi peran dan tanggung jawab profesi, dan memperhatikan nilai-nilai dalam pengambilan keputusan etis (Anwar \& Rosa, 2019). IPE tidak hanya bermanfaat bagi pasien tetapi juga memberikan kepuasan kepada tenaga kesehatan karena melalui kolaborasi akan meningkatkan dan mengoptimalkan peran antar profesi kesehatan dalam pengambilan keputusan tentang pengobatan dan perawatan yang berfokus pada kebutuhan pasien secara komprehensif dengan memperhatikan kontribusi dari masing-masing profesi kesehatan (Titania, 2018).

Beberapa penelitian telah membuktikan dampak positif dari penerapan Interprofessional Education dalam pelayanan kesehatan. Pelayanann kesehatan dengan pembelajaran IPE memperbaiki kondisi kesehatan dan meningkatkan wawasan kesehatan pasien dan keluarga pasien yang lebih baik (Toman, et al., 2016). Hal ini didukung oleh penelitian yang dilakukan oleh Romijn, et al., (2018) menunjukan adanya perbedaan yang relevan pada proses kolaborasi antara profesi kesehatan, sehingga dibutuhkan adanya kolaborasi yang efektif antara profesi kesehatan (Romijn, et al., 
2018). Penelitian yang dilakukan oleh Hutchison, et al., (2011) juga menunjukan bahwa dengan adanya penerapan kolaborasi antar tenaga kesehatan dalam memberikan pelayanan kesehatan menghasilkan keberhasilan dalam memberikan pelayanan yang baik bagi pasien, rasa menghargai perbedaan antar profesi dan cara memanfaatkan keahlian dari masing-masing profesi secara optimal (Hutchison, et al., 2011).

\section{DAFTAR PUSTAKA}

Anwar, H., \& Rosa, E. M. (2019). Meningkatkan Komunikasi dan Kolaborasi dengan Interprofessional Education (IPE): Literature Review. Jurnal Keperawatan Muhammadiyah Alamat, 91-101.

Asmara, F. Y., Bakri, S., Dewi, D. P., Afifah, D. N., \& Kristina, T. N. (2019). Implementation of interprofessional education in community setting. Journal of Community Empowerment for Health, 2(2), 222-228. https://doi.org/10.22146/jcoemph.47513.

Fuadah, D. Z., Hapsara, S., \& Sedyowinarso, M. (2014). Kesiapan Mahasiswa untuk Belajar Kerjasama Interprofesi Dalam Perawatan Antenatal. Jurnal Ners, 9(2), 226-235.

Hutchison, M. S., Ennis, L., Shaw-Battista, J., Delgado, A., Myers, K., Cragin, L., \& Jackson, R. A. (2011). Great minds don't think alike: Collaborative maternity care at San Francisco General Hospital. Obstetrics and Gynecology, 118(3), 678-682. https://doi.org/10.1097/AOG.0b013e3182 297d2d.

Kusumaningrum, P. R., \& Anggorowati, A. (2018). Interprofesioanal Education (IPE) Sebagai Upaya Membangun Kemampuan Perawat Dalam Berkolaborasi Dengan Tenaga Kesehatan Lain. Jurnal Kepemimpinan Dan Manajemen Keperawatan, $\quad 1(1), \quad 14$. https://doi.org/10.32584/jkmk.v1i1.72.

Lapkin, S., Levett-Jones, T., \& Gilligan, C. (2013). A systematic review of the effectiveness of interprofessional education in health professional programs. Nurse Education Today, 33(2), 90-102. https://doi.org/10.1016/j.nedt.2011.11.006.

Liaw, S. Y., Zhou, W. T., Lau, T. C., Siau, C., \& Chan, S. W. chi. (2014). An interprofessional communication training using simulation to enhance safe care for a deteriorating patient. Nurse Education

\section{SIMPULAN}

Berdasarkan kajian pustaka yang disitasi dapat disimpulkan bahwa interprofessional education (IPE) merupakan cara untuk meningkatkan kemampuan dan kompetensi kolaborasi antar profesi kesehatan sehingga dapat menciptakan tenaga kesehatan yang professional, mampu bekerjasama, dan mampu menigkatkan kualitas pelayanan kesehatan.

Today, 34(2), 259-264. https://doi.org/10.1016/j.nedt.2013.02.019. Muktamiroh, H., Irmarahayu, A., \& Setyaningsih, Y. (2019). Recommendations of the Development of Interprofessional Education in a Faculty of Medicine. Jurnal Pendidikan Kedokteran Indonesia: The Indonesian Journal of Medical Education, 8(2), 97. https://doi.org/10.22146/jpki.44506.

Pratiwi, D. R., Adespin, D. A., \& Soeharto, B. P. (2018). Faktor Yang Berhubungan Dengan Kinerja Mahasiswa S-1 Pendidikan Dokter Universitas Diponegoro Dalam Pelaksanaan Kegiatan Interprofessional Education Tahun 2017. Diponegoro Medical Journal (Jurnal Kedokteran Diponegoro), 7(2), 667-675.

Romijn, A., Teunissen, P. W., De Bruijne, M. C., Wagner, C., \& De Groot, C. J. M. (2018). Interprofessional collaboration among care professionals in obstetrical care: Are perceptions aligned? BMJ Quality and Safety, 27(4), 279-286. https://doi.org/10.1136/bmjqs-2016-006401

Sudarmi, S., Bertalina, B., \& Aprina, A. (2020). Efektifitas penerapan interprofessional education-collaborative practice (IPE-CP) tentang gizi seimbang terhadap pengetahuan dan sikap ibu hamil. AcTion: Aceh Nutrition Journal, 5(1), 71. https://doi.org/10.30867/action.v5i1.212.

Sulistyowati, E. (2019). Interprofessional Education (IPE) Dalam Kurikulum Pendidikan Kesehatan Sebagai Strategi Peningkatan Kualitas Pelayanan Maternitas. Jurnal Kebidanan, 8(2), 123. https://doi.org/10.26714/jk.8.2.2019.123-131.

Titania, E. L. (2018). Pentingnya Kolaborasi Antar Tenaga Kesehatan Dalam Menerapkan Keselamatan Pasien Echa. Journal of Chemical Information and Modeling, 53(9), 1689-1699. 
https://doi.org/10.1017/CBO97811074153 24.004

Toman, K. P., Probandari, A. N., \& R, A. B. T. (2016). Interprofessional Education (IPE): Luaran Masyarakat terhadap Pelayanan Kesehatan dalam Praktik Kolaborasi di Fakultas Kedokteran Universitas Sebelas Maret. Jurnal Sistem Kesehatan, 5(2), 123. https://doi.org/10.24198/jsk.v3i2.15003.

Wijoyo, E. B., Hananto, S., Program, M., Magister, S., Universitas, K., Program, D., ... Universitas, K. (2017). Pengembangan Pasien Virtual untuk Peningkatan Pendekatan. Jurnal Keperawatan Muhammadiyah, 2(1), 175-184.
World Health Organization. (2013). Kesehatan Mental dalam Kedaruratan. Jurnal Kependudukan Indonesia, 8(1), 37-52. http://ejurnal.kependudukan.lipi.go.id/ojs2 48jki/index.php/jki/article/download/21/15 Wulandari, H., Dewi, P. S., \& Purwara, H. B. (2018). Penerapan Interprofessional Education (IPE) Untuk Meningkatkan Ketrampilan Kerjasama Tim. Jurnal Kesehatan, 79-88. https://www.poltekkesjakarta1.ac.id/pener apan-interprofessional-education-ipeuntuk-meningkatkan-ketrampilankerjasama-tim-2. 